\title{
Biochemical and histologic evidence of plasmacytoid leukemia and salmon leukemia virus (SLV) in wild-caught chinook salmon Oncorhynchus tshawytscha from British Columbia expressing plasmacytoid leukemia
}

\author{
W. D. Eaton ${ }^{1}$, B. Folkins ${ }^{1}$, M. L. Kent ${ }^{2}$ \\ ${ }^{1}$ Malaspina University College, Biology Department, 900 Fifth St., Nanaimo, British Columbia, Canada V9R 5S5 \\ ${ }^{2}$ Deparlment of Fisheries and Oceans, Pacific Biological Station, Nanaimo, British Columbia, Canada V9R $5 \mathrm{~K} 6$
}

\begin{abstract}
Seven of 118 wild-caught chinook salmon Oncorhynchus tshawytscha had histologic signs of plasmacytoid leukemia (PL). A pooled tissue sample from 2 of these PLpositive fish was examined and found to be infected with a retrovirus as indicated by the elevated reverse transcriptase activity associated with a density of $1.17 \mathrm{~g} \mathrm{~cm}^{-3}$ in sucrose and polypeptides with identical electrophoretic mobilities to those of the purified salmon leukemia virus (SLV). The virus from the wild-caught chinook salmon was serologically identical to SLV, as anti-SLV hyperimmune rabbit antisera reacted with the 82,43 , and $27 \mathrm{kDa}$ polypeptides of both purified SLV and the wild-caught chinook salmon. Thus, it appears that SLV-associated PL occurs, at least at a low level, in wildcaught chinook salmon.
\end{abstract}

KEY WORDS: SLV - Wild-caught salmon - Plasmacytoid leukemia Retrovirus

A plasmacytoid leukemia (PL) has been causing mortalities in seawater netpen-reared chinook salmon Oncorhynchus tshawytscha in western British Columbia since 1988. The disease was shown to be of an infectious nature and was characterized as an anemia resulting from a proliferative infiltration of plasmablast-like cells into visceral organs and retrobulbar tissue of affected fish (Kent et al. 1990, Kent \& Dawe 1991, Newbound \& Kent 1991). A retrovirus, salmon leukemia virus (SLV), has been found in fish with PL but not in unaffected fish (Eaton \& Kent 1992). Furthermore, a retrovirus similar to SLV has now been found to be permanently expressed in a new cell line developed from PL-positive tissue (Eaton et al. 1993). Transmission studies using an SLV filtrate and chinook salmon indicate that the etiology of PL is due, at least in part, to infection with SLV (Kent \& Dawe 1991, 1993, Eaton \& Kent 1992).

A disease histologically similar to PL has been observed in chinook salmon (Hedrick et al. 1990, 1991, Morrison et al. 1990) and steelhead trout (MacConnell et al, 1991) in the United States. Although transmission studies have been inconclusive in determining the etiology of this disease, an intranuclear microsporidian, Enterocytozoon salmonis, has been observed in many, but not all, of these diseased fish. Transmission studies in our labs suggest that neither E. salmonis nor Renibacterium salmoninarum (etiologic agent of bacterial kidney disease) are the etiologic agent of PL (Kent \& Dawe 1991, 1993, Newbound \& Kent 1991, Eaton \& Kent 1992). There is little doubt that these 2 agents could act as co-factors in SLV-infected fish, resulting in exacerbation of PL, similar to other immunosuppressive diseases. However, this relationship needs further study.

Kent et al. (1993) showed that horizontal transmission of PL, and therefore SLV, does occur, although very rarely. In addition, Eaton et al. (1994) demonstrated that SLV infection results in a bimodal viremia, in which the second viremic episode probably continues until the fish recovers or dies. This raises questions of some concern as to whether SLV is present in wild or wild-caught populations of chinook salmon, whether it 
causes disease in them, and could any interaction between such fish and those in hatcheries or netpens contribute to an increase in PL. These types of interactions of diseases between farmed and wild or wildcaught salmon are of great interest to federal and provincial fisheries agencies in British Columbia, Canada. Consequently, a survey was conducted to determine if PL and/or SLV occurs in fish outside of the seawater netpens (i.e. wild-caught chinook salmon).

During 1991 and 1992, 118 chinook salmon were collected from the Strait of Georgia, Canada, by a commercial troller and analyzed for evidence of PL and SLV. Visceral organs and gills were collected, preserved in Davidson's solution, and processed for histologic examination using standard methodologies (Humason 1979). One additional wild-caught chinook salmon was collected independently by a different commercial fisherman. The tissues were preserved in $10 \%$ buffered formalin, and then processed for histologic examination. However, due to the formalin fixation, these tissues were unavailable for use in any other analysis.

Seven of the 118 fish collected exhibited histological changes consistent with mild or early $\mathrm{PL}$, including mild interstitial hyperplasia of hemopoietic elements in the kidney with an increase in blast cells, and a moderate increase in numbers of mature lymphoid cells and immature plasmablast cells throughout the sinusoids of all fish. Two fish exhibited infiltration of plasmablasts and other lymphoid cells throughout the lamina propria and submucosa of the lower intestine (Figs. $1 \& 2$ ). The liver of 1 fish showed focal accumulations and perivascular and peritubular cuffing comprised of these cells (Fig. 3). Moderate infiltration of plasmablasts was observed in the pancreas of 2 fish. In addition, the fish collected by the commercial fisherman exhibited histologic changes consistent with the full manifestations of PL as described by Kent et al. (1990). The microsporidian Enterocytozoon salmonis was not found in any fish examined in this study.

Kidney and spleen tissues from 2 of the $118 \mathrm{fish}$, with the most extensive PL-like lesions, were selected for biochemical and serological analysis. To provide adequate material for study, the samples were pooled. Analysis of this sample showed the presence of a virus with biochemical and serological properties identical to SLV. The methods of Eaton \& Kent (1992) were used to show that reverse transcriptase (RT) activity was

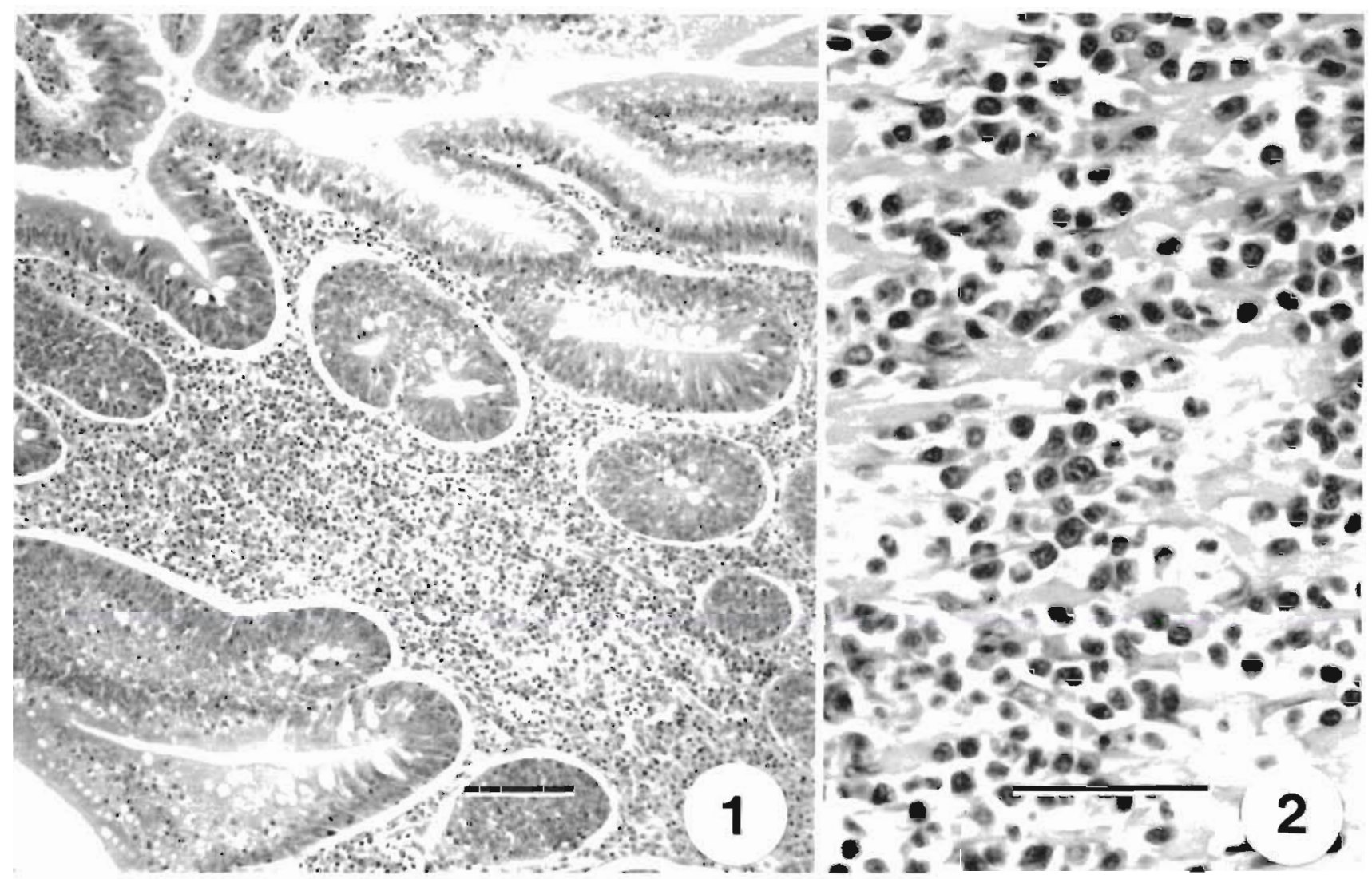

Figs. 1 \& 2. Oncorhynchus tshawytscha. Lower intestine of wild-caught chinook salmon with histological changes suggestive of mild or early PL; infiltration of lymphoid cells, many which resemble plasmablasts, in lamina propria. Fig. 1: scale bar $=100 \mu$ m; 


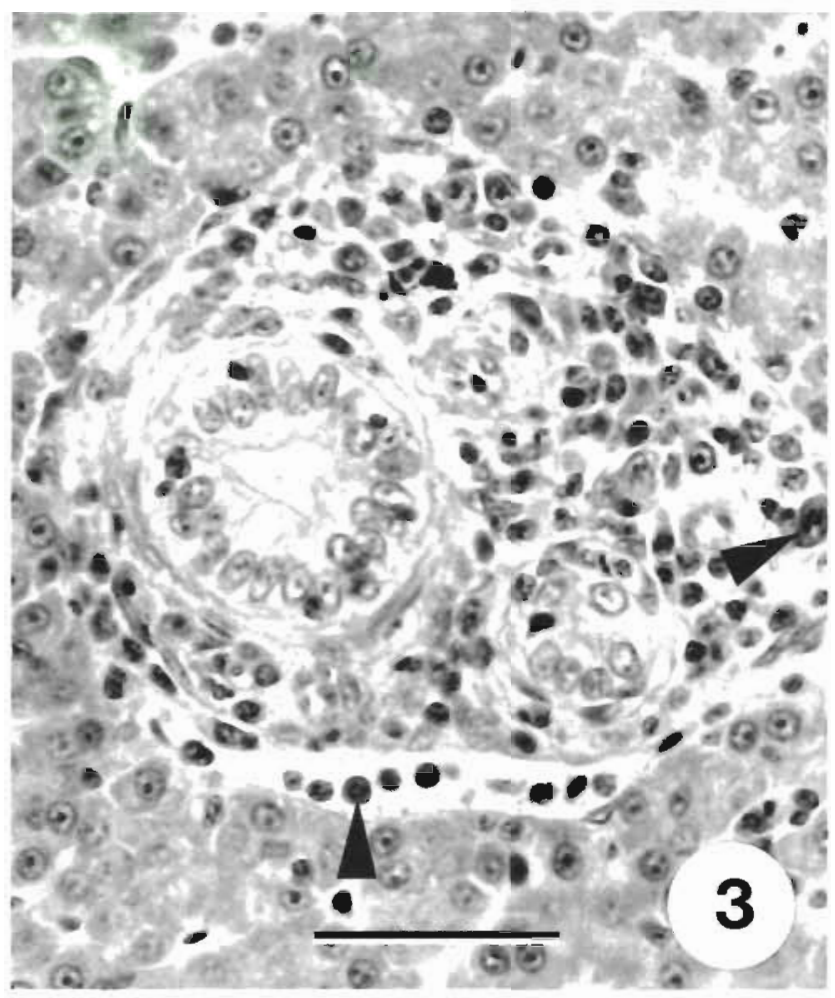

Fig. 3. Oncorhynchus tshawytscha. Liver of wild-caught salmon with histological changes suggestive of mild or early $\mathrm{PL}$; peritubular cuffing of lymphoid cells, many which resemble plasmablasts (arrowheads). Scale bar $=50 \mu \mathrm{m}$

present in the sample from wild-caught chinook salmon, the snakehead retrovirus (SHRV) and purified SLV (positive controls), but not in unaffected chinook salmon tissue (Table 1). The pooled sample was then processed through a sucrose gradient, as described by

Table 1 Reverse transcriptase (RT) activity in tissue homogenates from wild chinook salmon with plasmacytoid leukemia (PL), salmon leukemia virus, snakehead retrovirus, and normal chinook salmon. Samples were prepared as described in the text and were analyzed for RT, DNA polymerase (DNAP), or terminal transferase activity using 20 $\mathrm{hg}$ of the RT-specific (poly rA) or DNAP/terminal-transferase-specific (poly dA) primers combined with $50 \mu \mathrm{l}$ of sample and $50 \mu \mathrm{l}$ of reaction mixture $\left(0.1 \mathrm{M}\right.$ Tris- $\mathrm{HCl}$, pH $8.3,0.5 \mathrm{M} \mathrm{KCl}, 1.0 \mathrm{M} \mathrm{MnCl}_{2}, 4.0 \mathrm{mM}$ dithiothreitol, and $20 \mu \mathrm{Ci} \mathrm{ml}{ }^{-1}{ }^{3} \mathrm{H}-\mathrm{TTP}$ ). The acid-precipitable cpm were determined at the start of the assay $\left(T_{0}\right)$ and after 60 min incubation at $22^{\circ} \mathrm{C}\left(T_{60}\right)$. A ratio of the $T_{60}-T_{0} \mathrm{cpm}$ using the 2 different primers that is $\geq 4$ is considered positive for RT activity

\begin{tabular}{|c|c|c|c|}
\hline Sample & $\begin{array}{c}\text { Synthetic } \\
\text { poly rA } \\
T_{60}-T_{0}\end{array}$ & $\begin{array}{c}\text { rimer used } \\
\text { poly dA } \\
T_{60}-T_{0}\end{array}$ & Poly $\mathrm{rA} /$ poly $\mathrm{dA}$ \\
\hline Unaffected chinook & 1050 & 1368 & 0.76 \\
\hline $\mathrm{PL}+$ wild chinook & 23370 & 2327 & 10.04 \\
\hline Salmon leukemia virus & 18886 & 2011 & 9.38 \\
\hline Snakehead retrovirus & 17001 & 2053 & 8.28 \\
\hline
\end{tabular}

Eaton \& Kent (1992). Polyacrylamide gel electrophoresis (PAGE) analysis (Laemmli 1970) of an RT-positive fraction from the sample, with a density of $1.17 \mathrm{~g} \mathrm{~cm}^{-3}$ and purified SLV indicated that both had proteins with identical molecular weights (Fig. 4).

An immunoprecipitation assay was conducted in which hyperimmune anti-SLV antisera developed in rabbits against purified SLV was reacted with purified SLV and the wild-caught chinook salmon virus. The methods used were similar to those described by Hedrick et al. (1986), except that $0.1 \mathrm{ml}$ of purified SLV or the wild-caught chinook virus was disrupted in $0.5 \% \mathrm{NP}-40$ for $1 \mathrm{~h}$, mixed with $0.1 \mathrm{ml}$ of the antisera and incubated overnight at $4{ }^{\circ} \mathrm{C}$ before $50 \mu \mathrm{l}$ of the $40 \%$ Protein A-Sepharose CL-4B (Pharmacia) solution was added to capture any protein:antisera complexes. The SLV and the wild-caught chinook salmon virus were shown to be serologically identical as the antiSLV antisera reacted with the 82, 43 and 27 kDa polypeptides of both viruses in the immunoprecipitation assay (Fig. 5). This is similar to the results of Deshayes et al. (1977), who found that antibodies from cattle with bovine leukemia virus (BLV)-associated leukemia (another retroviral-induced leukemia) reacted with the capsid protein (about $24 \mathrm{kDa}$ ) and one of the envelope proteins of BLV. Eaton et al. (1994) suggest that the 27 , 82 and $43 \mathrm{kDa}$ polypeptides of SLV represent the capsid protein, one of the envelope proteins, and a capsid precursor protein, respectively.

Retroviruses have been found in several species of wild fish and have been indicated as the etiologic agent of neoplasias in some cases (Winqvist et al. 1968, Walker 1969, Mulcahy \& O'Leary 1970, Papas et al. 1976, Sonstegard 1976, 1980, Duncan 1978, Gross 1983, Anders et al. 1991, Martineau et al. 1991). This study has shown that SLV and PL occur, at least at a very low level, in fish outside of netpens as: (1) a chinook salmon collected by a commercial fisherman exhibited unequivocal histologic evidence of $\mathrm{PL}_{\text {; }}$ (2) 7 wild-caught chinook salmon examined exhibited histopathologic evidence of mild or early $\mathrm{PL}_{\text {; }}$ and (3) a tissue sample pooled from 2 of these fish contained a virus that was biochemically and serologically identical to SLV. However, from this study, we cannot determine an overall prevalence of either PL or SLV in the wild-caught salmon of the Strait of Georgia.

The origin of SLV is unknown and will likely be difficult to ascertain. However, it is possible that PL and SLV may have been present in both wild and cultured fish for years, but have been misdiagnosed as bacterial kidney disease (BKD), due to similarity of the pathologic changes of the 2 diseases. It is of interest that a 


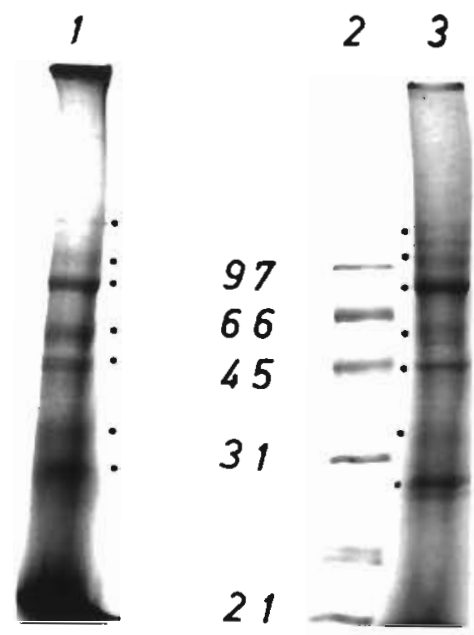

Fig. 4. Polyacrylamide gel electrophoresis of sucrose gradient purified salmon leukemia virus (SLV) and the retrovirus from wild-caught chinook salmon. Molecular weights ( $k D a$ ) of the viral polypeptides were determined by the electrophoretic mobility of BioRad protein size standards shown that were run in the same gel. Lane 1: SLV; Lane 2: standards; Lane 3: virus from wild-caught chinook salmon. Dots indicate viral proteins

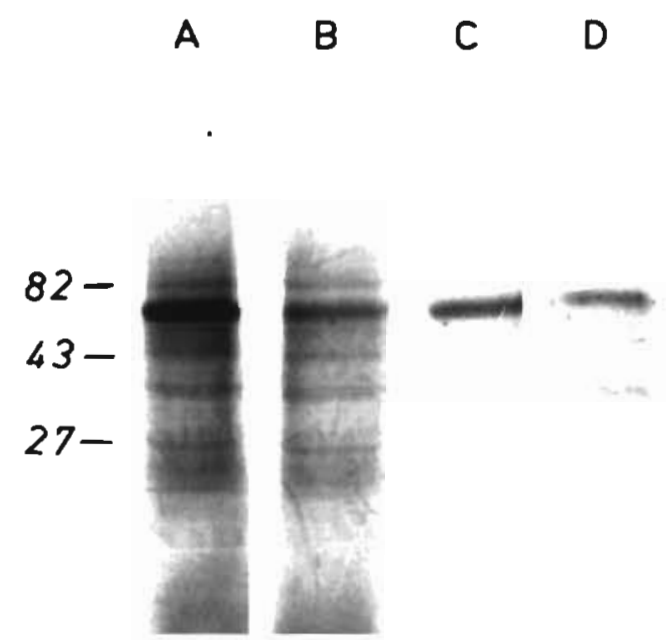

Fig. 5. Polyacrylamide gel electrophoresis of SLV (Lane A), virus from wild chinook salmon (Lane B), and tissue from uninfected chinook salomon (Lane C) immunoprecipitated with hyperimmune anti-SLV antisera developed in rabbits. Lane $D$ : antisera only (dots indicate immunoglobulins). Molecular weight of the viral protein in $\mathrm{kDa}$

disease histologically indistinguishable from PL was first observed in chinook salmon reared at a freshwater hatchery in Washington state, USA, in 1974, and many of the affected fish were released for seaward migration (Harshbarger 1984).

The presence of SLV in wild-caught fish is important from a management perspective but does not answer the question of origin of SLV. It is not known if these
PL- and/or SLV-positive fish were escapees from seawater netpens, were originally from government enhancement hatcheries, or were truly wild fish. It is possible, although unlikely, that horizontal transmission of SLV and PL has occurred between wild and cultured fish as experimental evidence shows that horizontal transmission of PL/SLV can occur very rarely (Kent et al. 1993), and that SLV infections result in a bimodal viremia (Eaton et al. 1994), thus increasing the risk of horizontal transmission. However, such an origin is unlikely as it is not typical of oncogenic retroviruses (Dahlberg 1988). It is more probable that horizontal transmission contributes to the spread of $\mathrm{PL}$ within a particular culture holding facility.

The virus may have originated from previously unexpressed endogenous retroviral DNA sequences, some of which have been recently found in several salmonids (Moir \& Dixon 1988, Stuart et al. 1992). Kent et al. (1993) presented some preliminary evidence that PL may be vertically transmitted. Certainly this model is true with some of the murine leukemia viruses. It is possible that SLV is endogenous in various stocks of chinook salmon in the wild and in the salmon enhancement programs, and that some of these stocks were used to start the chinook salmon culture industry in British Columbia in the $1980 \mathrm{~s}$. This could have provided a source of virus, whose expression would be enhanced in the high density environment associated with aquaculture.

Many questions associated with SLV and PL in wildcaught salmon warrant further attention. What is the origin of the SLV/PL-positive wild-caught salmon (e.g. hatcheries, netpen escapees, truly wild)? Does exacerbation of other diseases, such as BKD, occur in wild, wild-caught and cultured stocks of chinook salmon as a consequence of the potential immunodeficiency resulting from SLV-associated PL? How widespread is SLV infection in wild, wild-caught or cultured chinook salmon? How is the virus/disease transmitted? What level of SLV-like proviral DNA sequences is present in Pacific salmon and are those sequences expressed? What is the role of oncogenes in the development of PL? Research projects have been started in our laboratories to begin to address these important questions. These may give us the first clues as to the origin of SLV and its importance in chinook salmon and other Pacific salmonids.

Acknowledgements. This work was supported by grants from the Natural Sciences and Engineering Research Council of Canada Science Subvention and Strategic Programs. We thank Drs G. N. Frerichs and D. E. Onions (University of Stirling and University of Glasgow) for the snakehead retrovirus. Special thanks to Mr Ralph Scheurle and Ms Jody Wonnenberg at the University of Victoria Animal Health Care Unit for their efforts in development of the hyperimmune rabbit antisera. 


\section{LITERATURE CITED}

Anders, K., Hilger, I., Moller, H. (1991). Lentivirus-like particles in connective tissue tumours of fish from German coastal waters. Dis. aquat. Org. 11. 151-154

Dahlberg, J. E. (1988). An overview of retrovirus replication and classification. Adv. Vet. Sci. Comp. Med. 32: 1-16

Deshayes, L., Levy, D., Parodi, A. L., Levy, J. P. (1977). Proteins of bovine leukemia virus. J. Virol. 21(3): $1056-1060$

Duncan, I. B. (1978). Evidence for an oncovirus in swimbladder fibrosarcoma of Atlantic salmon Sa o salar L. J. Fish Dis. 1: 127-131

Eaton, W. D., Folkins, B., Bagshaw, J., Traxler, G., Kent, M. L. (1993). Isolation of a retrovirus from two fish cell lines developed from chinook salmon (Oncorhynchus tshawytscha) with plasmacytoid leukemia. J. gen. Virol. 74: $2299-2302$

Eaton, W. D., Folkins, B., Kent, M. L., Dawe, S., Newbound, G. C., Zinkl, J. (1994). Preliminary analysis of the polypeptides of the salmon leukemia virus (SLV) and evidence for development of a bimodal cell-free viremia following SLV infection. Vet. Microbiol. (in press)

Eaton, W. D., Kent, M. L. (1992). A retrovirus in chinook salmon (Oncorhynchus tshawytscha) with plasmacytoid leukemia and evidence for the etiology of the disease. Cancer Res. 52: 6496-6500

Gross, L. (1983). Tumors, leukemia, and lymphosarcomas in fish. In: Gross, L. (ed.) Oncogenic viruses, 3rd edn. Pergamon Press, Elmsford, NY, p. 103-116

Harshbarger, J. C. (1984). Pseudoneoplasms in ectothermic animals. Natl Cancer Inst. Monogr. 65: 251-273

Hedrick, R. P., Eaton, W. D., Groberg, W. G., Boonyaratapalin, S. (1986). Characteristics of a birnavirus isolated from cultured sand goby Oxyeleotris marmoratus. Dis. aquat. Org. 1: $219-225$

Hedrick, R. P., Groff, J. M., Baxa, D. V (1991). Experimental infections with Enterocytozoon salmonis, Chilmonczyk, Cox, Hedrick (Microsporea): an intranuclear microsporidium from chinook salmon Oncorhynchus tshawytscha. Dis. aquat. Org. 10: 103-108

Hedrick, R. P., Groff, J. M., McDowell, T. S., Willis, M., Cox, W. T (1990). Hematopoietic intranuclear microsporidian infections with features of leukemia in chinook salmon Oncorhynchus tshawytscha. Dis. aquat. Org. 8: 189-197

Humason, G. L. (1979). Animal tissue techniques. W. H. Freeman \& Co., San Francisco

Kent, M. L., Dawe, S. C. (1991). Experimental transmission of a plasmacytoid leukemia of chinook salmon, Oncorhynchus tshawytscha. Cancer Res. 50: 5679-5681

Kent, M. L., Dawe, S. C. (1993). Further evidence for a viral etiology in plasmacytoid leukemia of chinook salmon Oncorhynchus tshawytscha. Dis. aquat. Org. 15: 115-121 Kent, M. L., Groff, J. M., Traxler, G. S., Zinkl, J. G., Bagshaw,

Responsible Subject Editor: F. M. Hetrick, College Park, Maryland, USA
J. W. (1990). Plasmacytoid leukemia in seawater reared chinook salmon Oncorhynchus tshawytscha. Dis. aquat. Org. 8: 199-209

Kent, M. L., Newbound, G. C., Dawe, S. C., Stephen, C., Eaton, W. D., Traxler, G. S., Kiesser, D., Markham, R. F. (1993). Observations on the transmission and range of plasmacytoid leukemia of chinook salmon. AFS-FHS Newsletter 221(2): 1-3

Laemmli, U. K. (1970). Cleavage of the structural proteins during the assembly of the head of bacteriophage T4. Nature 227: 680-685

MacConnell, E., Shaw, T., Smith, C. E. (1991). Naturally occurring infection with intranuclear microsporidium Enterocytozoon salmonis in steelhead trout Oncorhynchus tshawytscha. Abstracts-14th annual AFS/FHS meeting, 31 July-3 August 1991, Newport, Oregon, USA. Fish Health Sec., American Fisheries Soc., Corvallis, p. 11

Martineau, D., Renshaw, R., Williams, J, R, Casey, J. W., Bowser, P. R. (1991). A large unintegrated retrovirus DNA species present in a dermal tumor of walleye Stizostedion vitreum. Dis. aquat. Org. 10: 153-158

Moir, R. D., Dixon, G. (1988). A repetitive DNA sequence in salmonid fishes similar to a retroviral long terminal repeat. J. mol. Evol. 27: 1-7

Morrison, J. K., MacConnell, E., Chapman, P. F., Westgard, R. L. (1990). A microsporidium-induced lymphoblastosis in chinook salmon Oncorhynchus tshawytscha in freshwater. Dis. aquat. Org. 8: 99-104

Mulcahy, M. F., O'Leary, A. (1970). Cell-free transmission of lymphosarcoma in northern pike, Esox lucius L. (Pisces: Esocidae). Experientia (Basel) 26: 891

Newbound, G. C., Kent, M. L. (1991). Experimental transmission of plasmacytoid leukemia in salmonid fishes. Dis. aquat. Org. 10: 159-166

Papas, T. S., Dahlberg, J. E., Sonstegard, R. A. (1976). Type C virus in lymphosarcoma in northern pike (Esox lucius). Nature 261: 506-508

Sonstegard, R. A. (1976). Studies of the etiology and epizootiology of lymphosarcoma in Esox (Esox lucius L. and Esox masquinongy). Prog. exp. Tumor Res. 20: 141-155

Sonstegard, R. A. (1980). Virus associated hematoporetic neoplasia in shellfish and fish. In: Yohn, D. S., Lapin, B. A., Blakeslee, J. R. (eds.) Advances in comparative leukemia research. Elsevier North Holland, Inc., New York, p. 227

Stuart, G. R., Dixon, B., Pohajdak, B. (1992). Isolation of a putative retrovirus pol gene fragment from trout. Comp. Biochem. Physiol. 102B(1): 137-142

Walker, R. (1969). Virus associated with epidermal hyperplasia in fish. Natl Cancer Inst. Monogr. 33: 195-207

Winqvist, G., Lundberg, O., Hellstroem, B. (1968). Skin tumors of northern pike (Esox lucius L.) II. Viral particles in epidermal proliferations. Bull. Off. int. Epiz. 69: $1023-1031$

Manuscript first received: May 17, 1993

Revised version accepted: January 27, 1994 